\title{
Legal-Economic Problems of Private Foreign Investment in Developing Countries
}

\author{
Gerald M. Meier
}

The widespread practice of national economic planning in developing countries is moving the problems of international private investment into a new context. To appreciate more fully the legal-economic issues that are emerging in this context, we need an analytical framework for appraising the investment laws and regulatory measures that might be adopted by an underdeveloped country to attain the double policy objective of encouraging a greater inflow of private foreign capital while, at the same time, obtaining from this capital a more effective contribution to the country's development program. The following discussion attempts to provide such a framework. In so doing, it bears directly on the lawyer's role as negotiator and counsellor on matters of foreign investment; in a broader sense, the analysis touches upon some formative principles and institutions of international economic law.

Our concern throughout is with "direct" private investment and with the national regulation of such investment by underdeveloped capital-recipient countries. ${ }^{1}$ Our exclusive concern with policies taken by the capital-receiving nations is designed to redress the imbalance in previous studies which have either looked forward to the creation of a foreign investment code in the form of a multilateral treaty, ${ }^{2}$ or

Gerald M. Meier, Professor of International Economics, Stanford University, received a B.A. degree from Reed College in 1947, a B.Litt. degree from the University of Oxford in 1952, a Ph.D. from Harvard University in 1953, and an M.A. (Hon.) from Wesleyan University in 1959. He has been a lecturer and consultant on development programs in Pakistan, Jamaica, and Nyasaland (Malawi) and is the author of three books on economic development.

1 The exercise of managerial control distinguishes "direct" investment from "portfolio" or "indirect" investment. The United States Department of Commerce defines direct foreign investments to include all those foreign business enterprises in which a United States resident person, organization, or affiliated group owns a twenty-five per cent interest, either in the voting stock of a foreign corporation or an equivalent ownership in an unincorporated foreign enterprise.

The justification for considering only direct investment is that portfolio investment is of negligible quantitative significance for newly-developing countries and can be expected to remain so.

2 Organization for Economic Co-operation and DEvelopment [hereinafter referred to 
have concentrated on measures adopted by the capital-exporting countries to encourage and protect foreign investment. ${ }^{3}$ The experience of the past two decades has made it increasingly evident that policies of the capital-recipient countries are more decisive in determining the quantity and quality of the private capital inflow than are the measures of the capital-exporting countries; for the host country has controlling power as the ultimate policymaker and can neutralize action taken initially by the investing country. ${ }^{4}$ Controls exercised by the host

as O.E.C.D.], Draft Convention on the Protection of Foreign Property (1962); The Promotion of the International Flow of Private Capital: Further Report by the SecretaryGeneral, U.N. EcoSoc Council. OFF. Rec. 32d Sess., at 31-42 (E/3492) (1961); Fatouros, An International Code To Protect Private Foreign Investment-Proposals and Perspectives, 14 U. ToRonto L.J. 77 (1961); Gardner, International Measures for the Promotion and Protection of Foreign Investment, 9 J. PuB. L. 176 (1960); Larson, Recipients Rights Under an International Investment Code, 9 J. Pub. L. 172 (1960); Lauterpacht, The Drafting of Treaties for the Protection of Investment, INT'x \& CoMP. L.Q. 18 (1962); Metzger, Multilateral Conventions for the Protection of Private Foreign Investment, 9 J. Pus. L. 133 (1960); Miller, Protection of Private Foreign Investment by Multilateral Convention, 53 AM. J. INT'L L. 371 (1959); Schwarzenberger, The Abs/Shawcross Draft Convention on Investments Abroad: A Critical Commentary, 9 J. Pub. L. 147 (1960); Snyder, Foreign Investment Protection: A Reasoned Approach, 61 Mrch. L. Rev. 1087 (1963).

The major proposals for a multilateral investment protection convention have been those of the British Parliamentary Group for World Government, the Council of Europe, the International Chamber of Commerce, the O.E.C.D., and the Abs/Shawcross Draft Convention on Investments Abroad. See Britssh Parliamentary Group for World Government, A World Investment Convention? (1959); Council of European Consultative Assembly, Possibility of Concluding an International Code for the Protection of FORETGN INVESTMENT IN UNDERDEVELOPED CoUNTRIES (Doc. No. As/JUR (12)) (1960); INTERNational Chamber of Commerce, Attracting Foreign Investment 9-12 (1960); O.E.C.D., supra; Draft Convention on Investments Abroad, 9 J. PUB. L. 116 (1960).

We cannot, however, be optimistic that any of the projected multilateral investment protection conventions will be effectively implemented. The possibility of securing agreement on a strong multilateral convention remains only a distant aspiration, given the divergent positions of investing and investee countries on the identity and content of "recognized" principles relative to the protection of foreign investment and the rights of host countries. To secure agreement among many states, covering widely varied types of investment, a multilateral convention would have to be drafted in excessively general terms. Moreover, newly developing countries are unlikely to accede to such a convention without escape clauses, such as a reservation of the right to expropriate in situations of "national emergency" or when demanded by the "public interest."

3 In an attempt to promote a larger flow of private capital to developing nations, several capital-exporting countries have adopted a range of measures that include tax incentives, state guarantees, and financial assistance to private investors. For a sampling of the extensive literature on these measures, see, e.g., BARLow \& WENDER, UnITEd STATES Tax Incentives to Direct Private Investment (1954); Fatouros, Government Guaran-

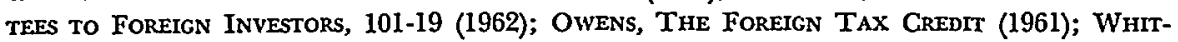
MAN, GOVERNMENT RISK-SHARING IN Foreign INVESTMENT (1965); Clubb \& Vance, Incentives to Private U.S. Investment Abroad Under the Foreign Assistance Program, 72 YALE L.J. 475, 487-502 (1963).

4 American businessmen have consistently believed that the role of the United States Government in impeding or promoting profitable private foreign investment is minor 
country over the conditions of entry of foreign capital, regulations of the operation of foreign capital, and restrictions on the remittance of profits and repatriation of capital are of crucial importance in determining the flow and contribution of external capital..$^{5}$

This close relation to public policy is a distinguishing factor in contrasting the problems of foreign investment in a less developed country with those in an advanced industrial country. To the potential investor in an industrially developed country the problems are essentially those of a long-term international business transaction, not presenting new or peculiar problems to the lawyer. ${ }^{6}$ The legal adviser to an investor in an underdeveloped country, however, faces very different policy and legal considerations. He will first have to ascertain what the legal or policy conditions for foreign investment are in the country concerned. There may be investment statutes or investment policy statements. And the investment adviser will be almost invariably led into the broader question of development planning in the country of investment. It is only in the framework of a development plan, with the complementary question of the allocation of resources, that an investment may have to be considered and proved acceptable. When it comes to investment in an underdeveloped country, the lawyer advising an enterprise is necessarily engaged in questions of public policy and transactions with the host government-all of which go beyond the usual technical legal questions to a wider range of considerations of a political, administrative, and economic character.

By shifting the emphasis to the policies connected with development planning in the recipient countries, our discussion focuses more directly on the primary determinants of the flow and contribution of foreign private capital. We shall begin by sorting out the various benefits and costs of private foreign investment from the viewpoint of a national development program (sections I and II). Against this

compared with the role of foreign governments and with market and economic forces outside the control of the investor's government. See NATIONAL INDUSTrial CoNfErence Board, Obstacles and Incentives to Prtvate Foreign Investment 1962-1964, at 39-42 (1965); U.S. Dep'T of CoMmerce, Factors Lmimting United States INVESTMENT ABroad, pt. 2 (1954).

A noted American tax lawyer, Stanley Surrey, reached a similar conclusion on the effectiveness of American tax policy in encouraging private investment in underdeveloped countries. See Surrey, Current Issues in the Taxation of Corporate Foreign Investment, 56 Colum. L. REv. 813 (1956).

5 See Address by Under Secretary of State George W. Ball, United Nations Conference on Trade and Development, Common Problems of Industrial and Developing Countries, 50 Dep't State Bull. 634 (1964).

6 Friedmann, Foreword-Foreign Investment Planning and Economic Development, 17 RUTGERS L. REv. 251, 253-56 (1963). 
conceptual background, we may then appraise the economic and legal effects of policy measures being pursued by developing countries to encourage an inflow of private capital and to regulate the operation of the foreign enterprise in conformity with developmental objectives (sections III and IV).

\section{Perspective on Development Planning}

Although public foreign capital has been the dominant source of international financing of development, there is increasing attention to the contribution that might come from private foreign sources. The American government, in particular, has continually emphasized the desirability of an increase in private foreign investment. President Truman's original Point Four program relied on governmentally financed assistance in public health, education, and agriculture, but for other activities it envisaged an outflow of private capital as a complement to public technical assistance. Successive foreign economic assistance bills have all acknowledged the desirability of governmental encouragement to private foreign investment. The promotion of more private American investment in Asia, Africa, and Latin America is a current priority objective of the Office of Development Finance and Private Enterprise within the Agency for International Development. Even though only a small amount of private capital, relative to government loans and grants, has gone to poor countries, ${ }^{7}$ the belief persists that capital from official sources is only a transitional arrangement and that foreign economic aid should be gradually replaced by private funds. To this end, considerable interest is being shown in measures that might promote foreign investment and allow it to contribute more effectively to the development of the recipient countries. ${ }^{8}$ The relationship between private foreign capital and development planning has therefore become of prime importance.

In their first surge of enthusiasm for development planning, many underdeveloped countries attempted to formulate comprehensive na-

7 For data on the magnitude and pattern of private capital flows to the poor countries, see I.M.F., Balance of PAYMENTS Yearbook (annual eds.); U.N. Dep'T Econ. AND Soc. Affairs, International flow of Private Capital (1962); U.S. Dep't of Commerce, U.S. Business Investments in Forelgn Countries (1960); Pizer \& Cutler, Foreign Investments 1964-65, Survey of Current Business, Sept. 1965, pp. 22-32.

8 Advisory Committee on PrIvate Enterprise in Foreign Aid, U.S. Agency for INT'L Dev., Report on Foreign Aid Through Private Inttiatrve (1965). See also the recommendations of earlier special Presidential commissions: COMM'N ON FOREIGN ECONOMIC Policx, Report (1954) (Randall Comm'n); President's Materials Policy Comm'n, ReSOurces for Freedom (1952) (Paley Comm'n); Gray, Report to the President on Foreign Economic Polictes (1950). 
tional plans which it was thought would permit a rational determination of priorities and ensure consistency and feasibility in making decisions about the allocation of resources. ${ }^{9}$ With the newly won political independence came a determination to seek economic independence. Development planning appeared to be an attractive alternative to what was interpreted as an historical pattern of detrimental dependence on foreign capital and foreign enterprise. Beyond the ideology of being free from "foreign domination," it was also possible to establish a strong case for development planning by criticizing the market mechanism and the inadequacy of private enterprise for the challenges of development. Arguments could be readily made that the market mechanism was either ineffective, unreliable, or irrelevant for developmental problems.

Most of the early development plans, therefore, concentrated almost exclusively on the public sector of the economy in determining the amount and composition of investment and looked only to public sources of foreign capital as the residual means of financing the development program. ${ }^{10}$ This early approach to development planning gave slight attention to the private sector of the economy and, a fortiori, to private foreign capital: an exclusionary or restrictive attitude toward foreign investment was characteristic of the initial efforts at development planning in many countries.

From the experience with planning, however, has come a realization that the comprehensive type of detailed planning is premature for many underdeveloped countries. The actual accomplishments of development planning have failed to fulfill original expectations. ${ }^{11}$ The difficulties of planning have only too often been underestimated, and the anticipated results from a public investment program and intergovernmental loans have been overestimated. Although a few of the less developed countries may have already laid the administrative, social, and educational groundwork that is essential for implementing a complex development plan, and although a few governments may possess the necessary political powers and administrative skills, most of the poor countries are not yet capable of undertaking the comprehen-

9 For a more extensive examination of the nature, scope, and techniques of development planning, see generally Meler, Leading Issues in Development Economics 415567 (1964), and references cited therein.

10 Planning Economic Development passim (Hagen ed. 1963); U.N. Group of ExPERTS, REPORT ON PLANNING FOR ECONOMIC DEVELOPMENT passim (1964); The Increasing Role of the Public Sector, 1960 Econ. SURvex of AsIa ANd THE Far EAsT 53 (1961); A Decade of Development Planning and Implementation, Economic Bull. for Asia and the Far East, Dec. 1961, p. 6.

11 cf. U.N., WORLd ECONOMIC SURVEY - 1964, at 99-118 (1965). 
sive type of planning that entails numerous governmental decisions of a direct and specific character. Certain undesirable results of comprehensive planning are now recognized: in practice, this type of planning has accentuated inflationary pressures, reacted on the supply of private entrepreneurship and hindered the full realization of investment potentials in the private sector, led to inefficient industrialization with projects that are handicapped by technical difficulties and excess capacity, and neglected the strategic importance of agricultural growth and export promotion. ${ }^{12}$

Against this background, there has been in recent years a marked retrenchment from the earlier enthusiasm for comprehensive centralized planning. A number of developing countries are now attempting to place more reliance on decentralized regulation: the emphasis is shifting to the improvement and guidance of the market mechanism and the provision of economic incentives. In this lighter type of planning, government policies are becoming more sensitive to the need for strengthening the general preconditions of development by providing social and economic overhead capital, establishing markets by institutional arrangements, and improving the efficiency of markets. It is also being realized that many of the policy measures that can affect individual action are not of the usual monetary or fiscal type, but rather those involving the legal and institutional framework, such as land tenure legislation, commercial law, and property rights. With this diminished concentration on the public sector, there is now greater potential scope for the private sector.

Similarly, developing countries now recognize that it is necessary to supplement the limited availability of public capital with capital from private sources if the chronic problems of scarcity of capital and shortage of foreign exchange are to be alleviated. Many countries have also come to appreciate that an inflow of private capital may offer some unique qualitative advantages over public capital. A persistent problem has been that the government of a poor country may not have the immediate capacity to employ additional capital assistance productively, in the sense of having the investment cover its costs and also yield a reasonable increase in income. The country's capital absorptive capacity is low when it is short of people who are capable of designing, constructing, and operating projects which use substantial amounts of capital. No such problem of productive use arises with private foreign capital; by its very nature, a foreign investment neces-

12 See Waterston, Development Planning-Lessons of Experience passim (1965); Watson \& Dirlan, The Impact of Underdevelopment on Economic Planning, 79 Q.J. ECON. 167 (1965). 
sarily entails the identification of an economic opportunity, the formulation of a productive project, and its efficient implementation. Direct foreign investment has the quality of carrying with it an integral ingredient of technical assistance-managerial and technical knowledge which are in even shorter supply than capital. As an instrument for transmitting technical and organizational change, the private foreign investment has a distinct advantage over foreign public capital.

As a result of the course of development planning, the policies now taken by the host countries with respect to private foreign investment reveal a mixed picture of both restrictions and incentives. On the one side, the foreign investor's freedom of action may be constrained by a variety of governmental regulations that exclude private foreign capital from certain sectors of the economy, limit the extent of foreign participation in ownership or management, specify conditions for the employment of domestic and foreign labor, limit the amount of profits, and impose exchange controls on the remission of profits and the repatriation of capital. And yet, during recent years, a progressive liberalization of policy toward private foreign investment has occurred, and a number of investment incentive measures have been recently adopted or are under consideration. These incentive devices include assistance in securing information on investment opportunities, establishment of overhead facilities such as industrial estates, protective tariffs on imports that compete with local commodities produced by foreign enterprise, exemptions from import duties on necessary equipment and materials, the granting of exchange guarantees or privileges, tax concession schemes for the encouragement of desired new investments, and special legislation for the protection of foreign capital.

If recipient countries have assumed a more positive attitude toward foreign private investment, so too have foreign investors come to realize that the practice of development planning need not in itself be inimical to the promotion of a larger inflow of private capital. Development planning now involves much more than a public investment program, and the practice of planning is not to be confused with the issue of public ownership and control. The essence of development planning is the formulation and coordination of a set of policies to achieve explicit objectives. In doing this, a plan may stress the complementary relationship between the public and private sectors and may include policies designed to induce and assist action in the private sector. Although a development plan reserves some areas of investment for the public sector, there is at least, on the other side, a clear statement of policy regarding areas in which private investment is desired. A development plan can be of service to the foreign investor 
when it expressly defines the particular role assigned to the private sector, indicates more clearly the existence of investment opportunities, facilitates advance calculation, and reduces the foreign investor's uncertainties regarding his position vis-à-vis the domestic private and public industrial sectors.

An American government report, for example, lists several advantages that private enterprise may gain from national planning by underdeveloped countries:

a) Competent development planning, by emphasizing statistical information and a quantitative framework for future targets and goals, creates a more dependable environment for evaluating business opportunities and risks than now exists in many less developed countries.

b) Planning may define more exactly and more reliably the fields of activity in which government and private business, respectively, are expected to provide the main leadership and activity.

c) Careful planning facilitates the timely provision of publicly financed installations, such as roads, irrigation facilities, or power plants, which are important to the growth of private investment. To the extent that development planning improves the use of resources for development, the basic facilities to support a vigorous private sector are provided more rapidly and effectively.

d) The planning process forces the planners to recognize the size of the requirements for sustained economic growth, and the consequent necessity of enlisting the forces of private enterprise in helping to meet these requirements.13

Although the prevalence of national development plans does not necessarily limit the scope for private activity and may actually promote more attractive business opportunities, it does mean that private investors must share with the government a common interest in accelerating development. The tasks of development require both more effective governmental activity and more international investment. But the private investor-and his counsel-must be aware of the developmental objectives and priorities of the host country in order to establish how the foreign investment fits into the country's development strategy. No longer is it simply a matter of private investors dismissing investment prospects with the complaint that a "favorable climate" does not exist; the meaning of a "favorable climate" calls

13 U.S. President's Task force on foreign Economic Assistance, An Act for International 'Development, Summary Presentation 102-03 (1961). 
for reinterpretation in terms of development planning. Nor need host countries contend that an inflow of private capital entails nothing but "foreign domination"; in the context of development planning, the effects of foreign investment need no longer be analyzed as if the undesirable features in the history of colonialism must be repeated. Development planning now allows the government to influence the performance of private foreign investment, but in doing this, the government should appreciate fully the potential contribution of this investment, and it should devise policies that will encourage a greater inflow of private capital and gain the maximum contribution toward the achievement of the country's development. This calls for more intensive analysis of the consequences of foreign investment and for more thought and ingenuity in devising new approaches that favor the mobilization of private foreign capital while ensuring its most effective "planned performance" in terms of the country's development program.

\section{Benefit-Cost Analysis of Private Foreign Investment}

To provide an analytical basis for understanding the rationale and effects of foreign investment policies in the host countries, we shall formulate in this section a benefit-cost analysis of private foreign investment. After establishing the possible advantages and disadvantages to the country receiving private capital, we may then proceed directly in the next section to an appraisal of existing policies.

At the outset, the influx of private capital contributes to the recipient country's development program in two general ways-by helping to reduce the shortage of domestic savings and by increasing the supply of foreign exchange. Foreign investment supplements domestic resources, thereby reducing the gap between the low level of available domestic savings and the higher level of investment requirements. A program of accelerated development also inevitably stimulates imports, and if, as is common, export earnings do not grow correspondingly, the developing country encounters a balance of payments deficit. This deficit must be financed by drawing down foreign exchange reserves, acquiring official foreign aid, or receiving private foreign capital. Otherwise, the developing country confronts a persistent foreign-exchange bottleneck that places a restraint on the pattern and pace of its development program. To the extent that the receipt of private foreign investment eases the shortage of foreign exchange, it permits a more rapid expansion in real income and removes the necessity of resorting to a drive toward self-sufficiency and the deliberate stimulation of 
import-substitution industries out of deference to foreign exchange considerations.

Beyond this initial contribution, the essence of the case for encouraging foreign investment is that over time, as the investment operates, the increase in real income resulting from the act of investment is greater than the resultant increase in the income of the foreign investor. There is a national economic benefit if the value added to output by the foreign capital is greater than the amount appropriated by the investor: social returns exceed private investors' returns. ${ }^{14}$ As long as foreign investment raises productivity, and this increase is not wholly appropriated by the investor, it follows that the greater product must be shared with others and that there must be some direct benefits to other income groups. These benefits can accrue to domestic labor in the form of higher real wages, consumers by way of lower prices, and the government through expanded revenue. In addition, and of most importance in many cases, there are likely to be indirect gains through the realization of external economies.

An increase in total real wages is a major direct benefit from an inflow of foreign capital. Not only does the addition of capital raise the productivity of a given amount of labor, but an inflow of capital may also allow a larger labor force to be employed. The latter effect is especially significant for those underdeveloped countries that are heavily populated and have a surplus supply of labor relative to other factors of production. The shortage of domestic capital is a bottleneck limiting the employment of labor in nonagricultural activities, and the only option for labor is to join the redundant agricultural labor force on the land. An inflow of foreign capital may make it possible to employ more labor in activities outside the rural sector. From this standpoint, the international flow of capital is an alternative to labor migration from a poor country: when international outlets for the emigration of labor are restricted, the substitution of domestic migration of labor out of the rural sector to an industrial sector becomes the most feasible solution. The social benefit from the foreign investment in the industrial sector is then greater than the profits on this investment, for the wages received by the newly employed exceed their former (low or even subsistence) real wages in the rural sector, and this excess should be added as a national gain.

Domestic consumers may also benefit from direct foreign investment.

14 For an expanded version of this analysis, see MEIER, INTERNATIONAL TRADE AND DeVElopment 92-99 (1963); StReEten, Economic InTEGRATION, ch. 4 (1961); MacDougall, The Benefits and Costs of Private Investment From Abroad: A Theoretical Approach, 36 ECON. RECORD 13 (I960). 
When the investment is cost-reducing in a particular industry, consumers of the product may gain through lower product prices. If the investment is product-improving or product-innovating, consumers benefit from better quality products or new products.

In order that labor and consumers might enjoy part of the benefit from the higher productivity in foreign enterprises, the overseas withdrawal by the investors must be less than the increase in output. But even if the entire increase in productivity accrues as foreign profits, there will still be a national benefit when the government taxes these profits or receives royalties from concession agreements. If the capitalimporting country is party to a double taxation agreement with the investing country, with full credit allowed on foreign taxes, it may enjoy this fiscal benefit by taxing the earnings of imported capital up to the rate of taxation in the investing country without impeding the inflow of capital.

The most significant contribution of foreign investment is likely to come from external economies-that is, from indirect benefits or favorable repercussions elsewhere in the economy outside the direct "internal" benefits of the investment project. ${ }^{15}$ The growth of one industry may yield external economies by allowing other industries to share in the facilities which it brings into existence in the form of such benefits as improved transportation and marketing services, labor skills, and organizational change, and by inducing a greater output from other industries which either supply it with materials or services, or use its product for further processing.

Besides bringing to the recipient country physical and financial capital, direct foreign investment also includes nonmonetary transfers of other resources-technological knowledge, market information, managerial and supervisory personnel, organizational experience, and innovations in products and production techniques-all of which are in short supply. As a carrier of technological and organizational change, the foreign investment provides "private technical assistance" and "demonstration effects" that are of benefit elsewhere in the economy. New techniques accompany the inflow of private capital, and by the example they set, foreign firms promote the diffusion of technological advance in the economy. This benefit is particularly important in a less developed country, for while domestic enterprises might not be adept in the art of innovating, they may offset this deficiency by imi-

15 The concept of "external economies" is discussed in detail by Arndt, External Economies in Economic Growth, 31 Econ. RECORD 192 (1955); Coase, The Problem of Social Cost, 3 J. LAW \& Econ. 1 (1960); Mishan, Reflections on Recent Developments in the Concept of External Effects, 31 Can. J. Econ. \& Pol. Scr. 3 (1965). 
tating the advanced techniques demonstrated by foreign firms. Technical assistance may also be provided to suppliers and customers of the foreign enterprise. In addition, foreign investment frequently leads to the training of labor in new skills, and the knowledge gained by these workers can be transmitted to other members of the labor force or to local firms which might later employ the newly trained workers.

Private foreign investment can also stimulate additional domestic investment in the recipient country. If the foreign capital is used to develop the country's infrastructure, ${ }^{16}$ it may directly facilitate more investment. Even if the foreign investment is in one industry, it may still encourage domestic investment by reducing costs to industries it supplies or creating demand in other industries; profits may then rise and lead to expansion in these other industries. Since there are so many specific scarcities in a poor country, it is common for investment to be of a cost-saving character by breaking bottlenecks in production. This stimulates expansion by raising profits in all underutilized productive capacity and by now allowing the exploitation of economies of scale that had previously been restricted. When the foreign investment results in a lower priced product, another industry that uses this product benefits from the lower price. This creates profits and induces an expansion in the second industry.

There is also considerable scope for the initial foreign investment to create external investment incentives by raising the demand for the output of other industries. The foreign investment in the first industry can give rise to profits in industries that supply inputs to the first industry, or that produce complementary products, or that produce goods bought by the factor owners who now have higher real incomes as a result of the inflow of foreign capital. A foreign investment that is product-improving or product-innovating may also have similar effects. A whole series of domestic investments may thus be linked to the foreign investment.

These external effects raise production outside the foreign enterprise, but the foreign investor cannot appropriate this additional output. The spillover goes unpriced and constitutes an uncompensated service. When the foreign investment yields an external economy, the

16 Infrastructure (Social Overhead Capital) is "the foundation underlying a nation's economy (transportation and communications systems, power facilities, and other public services) upon which the degree of economic activity (industry, trade, etc.) depends. It may include such intangible assets as the population's educational level and social attitudes, industrial skills and administrative experience. . . . The building up of a country's infrastructure, which generally involves projects with a high initial cost and a very long payoff period, is frequently carried out by the government or with its aid." McGrawHill, Dictionary OF MODFRN ECONOMics 261 (1965). 
social desirability (marginal social net product) of the foreign capital is therefore greater than its private profitability (marginal private net product). According to the criterion of national economic benefit, the case for governmental encouragement of private foreign investment is then strong.

Against these benefits, however, there are on the other side a number of costs of foreign investment that are detrimental to the host country's development plan. These costs may arise from special incentives and concessions offered by the host country, adverse effects on domestic saving, and pressure on the country's international balance of payments.

To attract foreign capital, the government of the host country may have to provide special facilities, undertake additional public services, extend financial assistance, or subsidize inputs to the foreign enterprise. These have a cost in absorbing governmental resources that could be used elsewhere. Tax concessions may also have to be offered, and these may have to be extended to domestic investors since the government may not be able to discriminate, for administrative and political reasons, in favor of only the foreign investor. In encouraging foreign investment, there is thus a fiscal cost through increased government expenditure or foregone revenue.

Once foreign investment has been attracted, it should lead to a higher level of real income and hence to an increase in domestic saving. This effect may be offset, however, by a redistribution of income away from domestic capital if the foreign investment competes with home investment and reduces profits in domestic industries. The consequent reduction in home savings would then be another indirect cost of foreign investment.

The most significant costs of foreign investment tend to be those associated with problems of balance of payments adjustment. Although the inflow of foreign investment initially provides foreign exchange, there may subsequently be pressure on the balance of payments when the foreign investment is serviced. Unless the capital inflow continues at an increasing rate, the time will come when the inflow of new capital is insufficient to cover the return outflow of interest, profits, and dividends on the accumulated investments. When a net outflow of foreign funds occurs, the host country has to generate a surplus in the current account of its balance of payments equal to the payments on account of the remittance of foreign earnings. A reallocation of resources then becomes necessary in order to expand exports or replace imports. And to accomplish this, the country may have to experience currency de- 
preciation or endure internal and external controls in the form of increased taxation, a tight monetary policy, import restrictions, or exchange controls. The adverse effects of these measures of balance of payments adjustment are indirect costs of foreign investment, to be added to the direct costs of the foreign payments.

The direct cost of paying for the investment need not be a matter of concern as long as the foreign investment is of sufficiently high productivity to raise domestic real income to an extent equal to, or greater than, the return on the investment to the foreign owners. If, however, the payment gives rise to a balance of payments problem, then the indirect costs come to the fore. When the country is not currently earning sufficient foreign exchange to cover the external servicing of the foreign investment, it will have to endure a loss of international reserves or adopt measures to adjust the balance of payments. External measures such as import quotas, tariffs, and exchange restrictions can be effective in suppressing the demand for imports, but they do so at the expense of productivity, efficiency, and real income. Internal measures of higher taxation and credit tightness involve the costs of reduced consumption and investment-results which are contrary to the very objectives of a development plan. And the alternative of currency devaluation may cause the country to incur the costs of a deterioration in its terms of trade, changes in income distribution, inflationary pressure, and shifts in resource allocation. In one form or another, the remittance of foreign earnings may therefore be a costly charge on domestic real income.

We have now classified the major consequences of foreign investment into those benefits or positive gains that contribute to the developing country's objective of increasing real income and those costs or negative effects that involve some sacrifice of the objective. The rational approach to the economic regulation of foreign investment would be to ensure that each foreign investment project meets the criterion of yielding a benefit-cost ratio greater than unity. ${ }^{17}$

With the foregoing conceptual framework in mind, we may now evaluate the investment laws and regulatory measures of developing countries.

17 It would be a misconception to express the criterion as "maximum benefit with minimum cost"; there is no policy that will meet the criterion of simultaneously maximizing gain (infinitely large) while minimizing cost (zero). See McKean, EfFicrency iN Government Through Systems analysis, Wrth Emphasis on Water Resource DevelopMENT 34-49 (1958).

For a more refined analysis, we should consider the time stream of benefits and the time stream of costs, and then discount these two streams down to the present value excess of benefits over costs. The rate of discount to be used depends on when it is most desired that the benefits should accrue-i.e., "social time preference." 


\section{Appraisal of Poligies Toward Private Foreign Investment}

The host country's regulatory measures over foreign investment are embodied for the most part in investment statutes, tax laws, controls over foreign trade, and foreign exchange regulations. Although these measures have generally arisen in an unsystematic and ad hoc fashion rather than as a closely coordinated set of policies, we can conveniently analyze their consequences in terms of an "allocation effect," a "distribution effect," and a "balance of payments effect."18 Each of these effects may go in either a positive direction in the sense of realizing the benefits from foreign investment, or in a negative direction in the sense of entailing the costs of foreign investment. By considering alternative investment policies in terms of these effects, we shall be able to assess their appropriateness in fulfilling the benefit-cost criterion.

\section{Allocation Effect}

The "allocation effect" of investment policies has two aspects: the inducement of foreign investment to one country rather than to another country and, within the recipient country, the allocation of the investment to one activity rather than to another. Most of the developing countries have now consolidated foreign investment legislation in an investment statute which sets forth both the privileges and obligations of foreign investors and specifies the administrative procedures, rules, and regulations governing the entry and operation of foreign investment. ${ }^{19}$ The statute attempts to encourage an inflow of foreign capital through the use of tax exemptions, tariff concessions, relaxation of exchange controls, some guarantee of nonexpropriation and nondiscrimination, and assurances for the repatriation of earnings or capital. After the prospective investment is subjected to a screening process, an "instrument of approval" is generally issued to the foreign investor qualifying under the statute: this details the assurances and guarantees granted by the host state as well as the obligations under-

18 These policies are often classified into those involving control over entry, control over operation, measures of taking, and measures of exclusion. The classification in the text is adopted because it provides a more direct approach to a benefit-cost analysis of these measures.

19 For recent lists of investment laws, see U.N. EcoSoc Councri, op. cit. supra note 2, annex IV; U.N. Secretariat, The Status of Permanent SOvereignty Over Naturat. WeAlth and Resources 7-62 (A/AC.97/5/Rev. 2) (U.N. Pub. Sales No. 62, v. 6) (1962). Texts of investment statutes are also periodically available from the World Trade Information Service of the U.S. Department of Commerce.

Indicative of the objectives sought by the legislation, these statutes-some of which may relate to domestic private capital as well as foreign-are variously called "Industrial Incentive Law," "Pioneer Industries Law," "Export Industry Encouragement Law," or "Production Development Law." 
taken by the investor regarding the amount, form, operation, and duration of the investment.

From an economic standpoint, the investment statute is effective in encouraging foreign investment when its provisions reduce nonbusiness risks, lower costs, or result in an increase in the net rate of return. To this end, tax concessions represent the major legislative effort to promote private investment. The concessions take three principal forms: relief from income and other taxes to "new and necessary industries," partial or complete exemption from duties on the importation of essential equipment and materials, and liberal depreciation allowances in the calculation of company taxes.

It is commonly believed that these concessions have provided some incentive to foreign capital. But their use can be overdone. For this type of legislation imposes costs on the government in the form of some loss of revenue, new differentials in tax burden distribution, and additional burdens upon administrative facilities. A central issue is whether these revenue, equity, and administrative costs outweigh the advantages that the use of the incentives may afford to a developing country. ${ }^{20}$ In examining this issue, Heller and Kauffman conclude that for many countries the tax system is relatively unimportant in inducing investment in comparison with other factors impeding investment, and that tax relief seems to be of only secondary importance in creating conditions conducive to industrial growth, especially when the objective is to increase the level of new investment instead of merely promoting reinvestment. ${ }^{21}$ Given the low utility of tax incentives, Heller and Kauffman submit that for most of the developing countries the costs of tax concessions outweigh the advantages. A study of industrial tax exemption in Puerto Rico also concludes that tax exemption:

$[\mathrm{m}]$ ay serve as an irrational or purely psychological inducement in the sense that it may be instrumental in encouraging the initiation of new business, but there may be little relationship between the effect of the inducement or the need for the assistance and the amount of subsidy actually received. ... There is little evidence to indicate that tax exemption has been an important incentive leading to the expansion of existing Puerto Rican firms. ${ }^{22}$

It is also contended that many of the new firms that use labor-intensive methods of production would have come to Puerto Rico even without tax exemptions.

20 See Helifer \& Kauffman, Tax Incentives for Industry in Less Developed CounTRIES 57-85 (1963).

21 Id. at 60-66.

22 Taylor, Industrial Tax Exemption in Puerto Rico 143 (1957). 
Tax holidays or reduced rates on taxable income are effective, of course, only when the investment yields substantial taxable profits. The assistance provided by tax exemption is, in fact, inverse to need: "as long as a firm experiences losses and needs assistance, it receives no income-tax subsidy; while the more successful and independent of aid it becomes, the more subsidy it obtains." 23 In the case of the IndustrialTax Exemption Act of Puerto Rico, it has been observed that "this process has resulted in a maldistribution of the income-tax subsidy, in which a few profitable firms have received the major share of the subsidy, while the remaining grantees that have needed assistance have received little or nothing." 24

Moreover, the foreign investor in a newly developing country is less interested in receiving an exemption after a profit is made than he is in being sure of a profit in the first instance. Measures that enable a company to earn a profit are more encouraging than the granting of exemptions after a profit is made. To raise profit expectations, the government may have to undertake additional public expenditures, particularly in providing public utilities, developing industrial sites, expanding labor training facilities, and furnishing statistical and information services. Governmental measures that increase labor productivity and help to stabilize the labor force are especially helpful in lowering the otherwise high marginal labor cost for a firm. With the same effect on the government's budget, these expenditures could be a more effective inducement for private investment than tax reduction. They would also reveal more directly the real cost of encouraging foreign investment. But governments have preferred the alternative of foregoing future tax revenue rather than incurring greater present expenditures.

Finally, it can be contended that a developing country might actually be offering excessive concessions to foreign capital. When confronting large foreign enterprises and competing among themselves for the short supply of foreign capital, small countries might well provide more by way of inducement than is necessary-especially when the concessions do not affect the total of investment forthcoming, but only its intercountry allocation. Some types of foreign investment (for instance, those to secure a necessary raw material or mineral) would go to one developing country or another, regardless of inducements, but the foreign enterprise may "shop around" and attempt to secure the most favorable terms from each possible source of supply. Special concessions in this case have no appreciable effect in raising the total flow 
of international investment, but they can affect the allocation as between one recipient country or another. The potentially recipient countries compete among themselves, and the competing concessions will largely cancel out-to the benefit of no one country. Competitive tax subsidies among developing countries, for example, may result in a process in which few of the advantages but most of the disadvantages of tax subsidies would remain. ${ }^{25}$ Negotiating independently, each developing nation offers greater concessions than it would if all the countries could act under a collective agreement regarding the maximum concessions that will be made. In this situation, there is a case for international discussion possibly leading to conventions or agreements that would eliminate the excessive competition. ${ }^{26}$ It is to the interest of developing countries as a group that the tax treatment should be as uniform as possible and that individual countries should not offer extra concessions except in agreement with the others.

Over-concessions are also made when, in order to avoid discriminatory policies, already existent investments are granted the same concessions that are necessary to encourage new capital. There is also the danger that the temporary preferential treatment. offered by concessions will attract the quick, speculative type of foreign investment that makes no long-run contribution to the economy, but simply takes advantage of the concessions. Even for a desired foreign investment that initially has a high benefit-cost ratio, concessions may be prolonged for too long a time: if the benefits come within a short period of time (as is likely), then prolongation of the concessions beyond this period is not justified. The cost of "overencouraging" certain types of foreign investment can be considerable. The problem therefore is not simply to consider the relative costs of different incentive devices, but also to devise sufficiently flexible instruments to allow selectivity in the conferral of concessions. The adoption of a selective investment statute, however, assumes that a necessarily high level of administrative capability exists so as to allow the conferring of broad discretionary powers on administrators who must be able to interpret the purposes of the law and its relationship to the country's development program. ${ }^{27}$

If the attraction of foreign investment to the country is one objective of an investment statute, another is to channel the investment into fields of high priority within the country. By a denial of concessions

25 Id. at 149.

26 See Kaldor, The Role of Taxation in Economic Development, in Problems IN EcoNOMic Development 185 (Robinson ed. 1965); Seers, Big Companies and Small Countries, 16 KYKLOS 603-05 (1963).

27 See Heller \& KaUfFMan, op cit. supra note 20, at 50-56. 
or absolute prohibition, developing countries now commonly screen foreign capital away from certain sectors of the economy that are reserved for public enterprise or domestic capital. Governmental grants of permits, licenses, leases, and concessions are an important means of controlling the acquisition and the extent of rights of foreigners in a country's natural resources. A growing body of constitutional and legislative provisions prescribes conditions which may be negotiated with private persons by the appropriate governmental authority. ${ }^{28}$ In many countries authorization or official approval is not granted for foreign investments in the traditional areas of mining, plantations, and public utilities, which are now reserved for national capital, either exclusively or by prescribing a share in ownership-control for nationals. Instead of supporting a continuation of the historical pattern of foreign investment, developing countries have shifted their emphasis to the encouragement of foreign capital in industries that process agricultural products, manufacture for export, or produce import substitutes. More and more the channeling of foreign capital appears predicated on a desire to stimulate industrialization, exercise sovereignty over natural resources, avoid the granting of monopoly positions to foreign enterprises, and protect domestic competitors.

Beyond the negative controls of outright exclusion, the positive inducements to attract foreign investment into desired channels fall into three main categories: a) tax exemptions or privileges for "approved investments," b) a tariff structure that induces "tariff factories" to replace imports and provides high protection on the final stages of production while reducing or removing tariffs on imported components, and c) the use of foreign exchange controls (especially multiple exchange rates and exchange licensing) in order to subsidize specific exports, favor the importation of necessary materials for approved investments, and allow larger remittance of earnings on desired investments.

Although their effects may be indirect and not readily apparent, import restrictions and exchange controls are now extremely important in determining the pattern of foreign investment. For the effects of a differentiated tariff structure and multiple exchange rates are equivalent to those of a scheme of subsidies and taxes, affecting the rate of return on foreign investment. When the country imposes prohibitive tariffs, or other import restrictions, against foreign manufacturers, the foreign manufacturer may be induced to escape the controls against his product by establishing a branch plant or subsidiary behind

28 For a discussion of what the legislatures of various countries have done to protect sovereign rights and national interest in natural resources see U.N. SECRETARIAT, op. cit. supra note 19 , at $7-20$. 
the tariff wall. Although the protection would have little effect in attracting supply-oriented industries, the inducement may be significant for the creation of "tariff factories" in market-oriented industries. It is particularly effective in encouraging the final stages of manufacture and assembly of parts within the tariff-imposing country when there is an import duty on finished goods while raw materials or intermediate goods remain untaxed.

\section{Distribution Effect}

Turning to the "distribution effect," we are now interested in how regulatory measures may affect the contribution of the foreign investment to local income. This contribution depends on the value of total output attributable to foreign investment and the proportionate share of local participation in the value of that output. Tax measures-consisting mainly of taxes on income and profits and export duties-are, of course, the major policies for reducing the share of the gross domestic product accruing to nonresidents. Under double-taxation agreements, the investee country receives the first share of profits taxation. To raise the share of local participation, however, additional measures are now also taken to control the operation of the foreign investment. In particular, many of the investment statutes require domestic partnership with the foreign investors, stipulating that a percentage of the capital in certain industries should be locally owned. The employment and training of nationals is also frequently sought by requiring that a certain percentage of the labor force of foreign-owned enterprises should be composed of nationals or by designating that a fixed percentage of the payroll should go to nationals. Minimum wage requirements and social welfare benefits are also designed to ensure a certain return to domestic labor from the operation of the foreign enterprise. There may also be requirements for the local production or purchase of components and supplies. Finally, there are commonly restrictions on the amount of profit that can be earned or limitations on the distribution of profits.

All these measures are intended to give domestic factors of production a larger share of the total value of the foreign enterprise's output. This intention, however, may conflict with the primary objective of attracting foreign investment. If domestic partnership limits the management and control of the enterprise, labor legislation is onerous, and allowable profits are not sufficiently attractive, then foreign investment will not be forthcoming, and the concessions previously discussed will be of no avail. It is difficult to determine the point when measures aimed at increasing the share of domestic income are more than offset by a loss in total income resulting from a decline in the inflow of 
foreign capital; however, at some point, policies designed to raise the benefit-cost ratio may result in no benefit whatsoever as foreign investment ceases.

\section{Balance of Payments Effect}

Especial attention should be given to the third effect of foreign investment measures-that on the balance of payments-insofar as a shortage of foreign exchange is a serious obstacle for all developing countries. If the development program is not to be constrained by a shortage of foreign exchange, policies must be instituted to ensure that the deficit is as small as possible and that the remaining irreducible deficit is accommodated by external financing. It is therefore important to analyze how policies affecting external private investment might lessen the pressure on the recipient country's balance of payments.

The initial inflow of foreign capital provides foreign exchange, and this is a benefit. But as noted previously, ${ }^{29}$ the outward flow of interest, profits, and dividends may require balance of payments adjustments that involve some cost. The return flow of capital is a charge on domestic real income that has to be transferred abroad either by increasing exports, decreasing imports, or receiving additional capital from overseas. To avoid or reduce this cost, local equity participation is frequently required. Many developing countries, under their foreign investment statutes and screening policies, also exclude foreign investments that do not contribute to an increase in exports or a replacement of imports, allowing entry only for investments which it is believed will earn sufficient foreign exchange to service their own transfers. Through exchange controls and taxation, the developing country may also limit the maximum transferable return on foreign capital by restricting the transfer of profits to some percentage of direct investment capital per annum, or by allowing earnings up to some percentage of registered foreign capital to be remitted at a lower official exchange rate and the remainder at only a higher free market rate. More severe exchange restrictions are generally applied to the repatriation of capital. A number of countries also attempt to limit transfer of income abroad by imposing a tax on dividends paid to nonresidents. Thus, by means of an absolute ceiling on income and capital transfers, unfavorable exchange rates, and increased taxation, the host country seeks to encourage the reinvestment of profits rather than the withdrawal with consequent pressure on the balance of payments.

On the surface, these measures seem sensible, but when examined more closely they too are subject to some criticism. A direct investment

29 See pp. 475.76 supra. 
may ease the balance of payments even if it does not occur in an export or import-replacing industry. What ultimately matters for the balance of payments is the productivity of investment and the impact of the investment on the total use of resources; the concern with the direct stimulation of exports or direct replacement of imports is a policy of misplaced concreteness. In a fundamental sense, the shortage of foreign exchange is a reflection of the shortage of domestic output; therefore, whatever does the most to increase domestic output will also contribute the most to easing the pressure on the balance of payments. As long as capital is allocated according to its most productive use and any excess spending associated with inflation is avoided, the necessary surplus of foreign exchange to service the foreign capital can be created indirectly. Even in the event that the investment yields an additional output of goods for only the home market, this will still be indirectly import-reducing-provided it does not involve inflationary financing. For the sale of the new products on the domestic market will necessarily divert expenditure away from imports. The investment may also indirectly increase export capacity or foster the production of import substitutes by freeing resources from other uses for transference to export or import-competing industries. The decisive point is that the allocation of foreign capital according to the criterion of highest social marginal productivity will also be the most favorable for debt servicing, since it maximizes the increase in income from a given amount of capital, thereby contributing to the growth of foreign exchange availabilities.

The concern with the reinvestment of profits may also be shortsighted. If the initial investment is of value in itself, but the foreign investor does not wish to reinvest his profits in the country, then attempts to force him to do so are more likely to result simply in a smaller inflow of foreign investment instead of any additional contribution from the reinvestment of profits. There is then a loss to the economy equal to the amount by which real national income would have risen from the investment less the real value of dividend payments abroad. Those firms that will not be deterred by the reinvestment requirement will be precisely those that would expect reinvestment to be profitable anyway, and reinvestment would occur without the governmental requirement.

Moreover, while the insistence on reinvestment does reduce the immediate demand for foreign exchange to pay dividends abroad, it simultaneously raises the amount of foreign investment on which further dividends may be earned and transferred in the future-without hav- 
ing the increased investment accompanied by any additional inflow of foreign exchange. If the intangible benefits-the managerial and technical assistance-from the original investment are realized within a short period of time, then the continued expansion of the foreign enterprise through retained earnings ceases to make any special contribution to the economy. But the ploughing-back of profit is tantamount to new foreign investment which expands the base on which profits may be made and causes the country's foreign service charges to become ever greater as the foreign equity increases. It may therefore be submitted that to restrain the rise in foreign service charges, the developing country should attempt to have as much of the subsequent expansion as is possible be financed from local equity sources. Alternatively, instead of encouraging further expansion of the initial investment, the host country may find it more desirable in the interests of diversification of the economy to encourage the investment of profits in other activities in the economy. To the extent that the initial investment gives rise to future investment elsewhere in the economy, the benefits of foreign investment become more widespread.

Out of concern for the balance of payments effect and also the distribution effect, many countries have attempted to secure local equity participation from the very beginning of the investment by excluding the foreign investor in certain industries unless the investment is in the form of a joint international business venture..$^{30}$ Ceteris paribus, an equity joint venture does allow more positive distribution and balance of payments effects than would $100 \%$ foreign ownership, but these advantages should not be overemphasized. There are also several disadvantages which may combine in certain cases to make it undesirable to encourage or enforce an equity joint venture.

If a foreign investor believed it was advantageous to participate in a joint venture, he would seek its establishment without the requirement of a foreign investment law. To the potential investor, the requirement cannot encourage more foreign investment than would have been forthcoming without the requirement; it can only operate in the direction of discouraging foreign investment. A joint venture will not be attractive to the foreign investor when the foreign enterprise has adequate capital and does not need local equity capital, there is no need to have a local partner to supply local knowledge, a branch opera-

30 See Joint INTERnational Business Ventures (Friedmann \& Kalmanoff eds. 1961); Blough, Joint International Business Ventures in Less Developed Countries, in SouthWestern Legal foundation, 2 Proceedings of the Institute on Private Investments ABroAd 513-35 (1960). 
tion is desired instead of the establishment of a local company, or when the participation of a local partner would affect the freedom of operation of an internationally integrated company. Given the foreign investor's disinclination to engage in a joint venture, the developing country's insistence on this form of investment will simply diminish the inflow of foreign capital.

From the standpoint of benefits to the recipient country, there are also conditions under which the joint venture cannot be considered as the preferred form of foreign investment. To require domestic participation is, of course, to tie the amount of foreign investment to the amount of domestic investment that will be forthcoming; even if the foreign investor were willing to invest in a joint venture, the foreign investment will be lost if domestic investors do not respond. Assuming there is adequate response, there is still a problem connected with the means of financing the domestic participation. If, on the one hand, local savings do exist and are mobilized by local participation in the foreign investment, the result may simply be to replace domestic investment which would otherwise have been made; the joint venture then has an opportunity cost by way of the foregone domestic investment. If, on the other hand, a significant supply of local savings is not already existent, but the joint venture presents an attractive opportunity for investment and the local investor borrows the necessary funds, then the joint venture has simply led to credit creation and inflationary financing of the local equity participation; this, in turn, will induce imports which are uncovered by an inflow of foreign exchange. The joint venture might also arise through the acquisition of a preexisting domestic firm-in this case actual or potential competition will be diminished, and an undesirable concentration of economic power may result. To the extent that joint ventures tend to predominate in largescale rather than smaller-scale enterprises, there is also less possibility for the imitation of the joint venture's production techniques elsewhere in the economy; the external economies from a large-scale joint venture may thereby be less than from a number of smaller-scale foreign enterprises which in the aggregate involve no greater amount of foreign equity than is present in the single large-scale joint venture.

Finally, the true alternative to the joint venture is not complete foreign ownership but rather no foreign equity participation at all. To the host country, the advantage of a joint venture is the acquisition of the intangible benefits and the nonmonetary transfer of resources associated with foreign investment without incurring the costs of $100 \%$ foreign equity. But along a scale of different forms of foreign invest- 
ment, the equity joint venture is only one of several alternative arrangements for securing the international transfer of technology and the acquisition of managerial skills. At one extreme on the scale is the foreign investment without local participation and without a time limit on its duration. This may be modified by a requirement that after the initial foreign investment, any subsequent expansion of the enterprise must come through local participation, in order to reduce the proportion of foreign equity over time; or a limited time duration may be imposed, after which the foreign enterprise must be sold to local investors. The joint venture extends this principle by limiting the amount of foreign equity and securing local participation at the outset. Compared with the alternative of a time limit on foreign investment and the eventual bringing of the foreign investment under local ownership and control, the joint venture is clearly less costly, insofar as the equity shares of the foreign enterprise will appreciate, and the repatriation of the sales proceeds imposes a foreign exchange burden.

If, however, the foreign know-how, managerial talent, and training facilities could be acquired without the foreign equity from the start, the developing country could then completely escape the costs of foreign financial involvement. To this end, contractual devices comprising engineering and construction agreements, technical services agreements, management contracts, or license or franchise arrangements may be superior to the equity joint venture. ${ }^{31}$ These contractual devices provide an extremely flexible means for directly transferring specialized technical and managerial knowledge of a proprietary nature from a foreign enterprise which is the outstanding-and the early-benefit of foreign investment, without the higher costs-which mount over time-of a foreign equity interest.

Instead of overemphasizing the institution of an equity joint venture, a developing country may therefore be better advised to seek the following mix: for the securing of foreign exchange-foreign public sources of capital (the World Bank, Inter-American Development Bank, Export-Import Bank, Development Loan Fund) that can supply funds

31 For an exposition of contractual devices, see generally U.N. EcoSoc CounciL, op. cit. supra note 2, If 29-197.

Considerable scope for technical collaboration agreements is indicated by the fact that more than 1,700 collaboration agreements were concluded in India during the period 1957-1963. KIDRON, ForeIGN INVESTMENTS IN INDIA 260 (1965). For discussion of the terms of collaboration agreements, see $i d$. at 281-85; KUST, ForEIGN ENTERPRISE IN INDIA 150-55 (1964); Postwar Foreign Investment in India, Economic Bull. for Asia and Far East, June 1962, pp. 13-16. 
in the form of long-term, low-interest loans and grants-in-aid; for the stimulation of the private sector-the relending of these funds to domestic enterprise through intermediate credit institutions such as local development banks or domestic finance corporations; ${ }^{32}$ for technical knowledge and business methods-more extensive use of contractual devices with foreign supplying enterprises. Through such a combination of public foreign capital with a management contract or technical collaboration agreement, the developing country may obtain both the capital and the technical, managerial, and training services at a lower cost than by insisting on an equity joint venture. The higher rate of return required for a direct equity investment is in essence a payment for foreign knowledge, and if this can be acquired through contractual devices while the foreign capital is received from governmental sources at a low rate of interest, then there is a distinct advantage in shifting the emphasis to management and service contracts. A greater demand for this type of activity should create an enlarged supply. If developing countries are attempting to depart from the traditional pattern of private foreign investment, so too is there a compelling need to seek new methods of foreign partnership to gain the benefits of "jointness" at reduced cost. The potentialities for thus combining local ownership with technical assistance from private foreign enterprise and financial aid from public sources can become of considerable practical importance.

\section{Protection of Private Foreign Investment}

Beyond their immediate effects, the foreign investment laws raise a number of questions regarding the ultimate problem of providing legal security for foreign capital. To remove "disincentives" on international investment there must be protection against the noncommercial risks of confiscation, currency inconvertibility, and adverse discriminatory treatment. While the existence of a favorable legal environment has been demonstrated in the more advanced industrial nations through historical experience, an equivalent tradition is lacking in the newly developing countries, and these countries must substitute for this through assurances and guarantees in their foreign investment statutes. This is important not only to encourage an inflow of foreign investment, but also to provide sufficient permanent security so that the foreign enterprise will be willing to undertake longer-term policies, such

32 For an elaboration of the role that these institutions can perform in providing long-term finance to private industry, see generally Boskey, Problems aNd Practices of Development Banks (1959); Diamond, Development Banks (1957); Diamond, Development Finance Companies, 2 Finance AND Development 97 (1965). 
as the investment in human resources, which will increase the benefits from the foreign investment.

When granting the foreign investor an instrument of approval or certificate of registration based on a foreign investment statute, the recipient government includes-along with the obligations of the foreign investor - a set of specific guarantees: these are generally guarantees against expropriation within a minimum time period, freedom from currency controls on the remittance of profits and capital repatriation, and promises of exemptions from taxes and import restrictions. In essence, a "foreign investment-development agreement" is reached, ${ }^{33}$ and the subsequent protection accorded foreign investment will depend in large part on the specific terms negotiated in this initial agreement between the private foreign investor and the recipient state. The adequacy of these guarantees under international law, however, is problematical. $^{34}$

The first problem in considering the international legal protection accorded by an instrument of approval is to determine whether the assurances by the recipient state are "contractual" in nature. If the instrument of approval is directly related to a specific agreement between the government and the foreign investor, contractual elements can be readily identified. If, however, the instrument of approval is simply issued under a general investment incentive program of the developing country, and these assurances are conveyed merely by way of a unilateral act on the part of the host government under the incentive program, then it becomes much more difficult to establish that an instrument of approval is "contractual" in nature.

Assuming a contractual obligation can be established, the next prob-

33 The term "economic development agreement" has been substituted for "concession agreement." See Hyde, Economic Development Agreements, in ACADEMIE DE DROIT INTERnational, I RecueIl des Cours 271 (1962); McNair, The General Principles of Law Recognized by Civilized Nations, 33 Brit. Yв. INT'L L. 2 (1957); Olmstead, Economic Development Agreements-Part II, 49 CALIF. L. REv. 504, 506 (1961).

"Foreign investment-development agxeement" is used here as a more general term covering all foreign investment agreements with developing states.

34 There are, of course, additional difficulties if the foreign investor seeks his remedy for alleged breach of the instrument of approval in the domestic courts of any country. If he sues in the courts of the state which has allegedly breached the agreement, it is unlikely that the court will reach a decision adverse to the state either because of a plea of sovereign immunity or because of its following the "new" law. Suits in the courts of another nation state will run into the barrier of sovereign immunity or, if a third party is the defendant, the barrier of the act of state doctrine. See generally LinLICH, THE Protection of Foreign INVestMent 3-113 (1965); ORfield \& RE, Cases on INTERNATIONAL LAw 285-311, 544-75 (rev. ed. 1965). The vagaries of these problems are outside the scope of this article. At point here is whether or not the investor has an international claim based upon the host state's alleged breach of the instrument of approval. 
lem is to determine whether a breach of the obligation has occurred. This requires, of course, an ascertainment of what is the proper law of the instrument-the municipal law of the state party to the contract, the municipal law of some other state, public international law, or possibly "the general principles of law of economic civilized nations." Problems then arise concerning the content of the governing law. Assuming that the governing law is not itself public international law, we finally confront the least settled aspects of the problem: in the absence of a treaty violation or a denial of justice, will a breach by the contracting state constitute a violation of international law? The fundamental issue is whether a right, initially created and subsisting within local municipal law, is protected by international law when the contracting state has itself changed the local law so as to end its obligations to a private party under the contract.

Some have submitted that:

$[W]$ here a contract between a sovereign and a foreign national, because of its legal incidence or economic substance, is impregnated with an international interest, the case for measuring the government's adherence to the contract against the standards of international law is compelling. This is so whether international law is introduced by way of the rules of state responsibility, or as the law governing the contract, or as an end product of the application of the general principles of law. ${ }^{35}$

And some have even argued that the doctrine of pacta sunt servanda applies to any agreement between a state and an alien, ${ }^{36}$ giving the agreement the status of an international treaty and leading to the conclusion that any breach by the state would constitute a violation of international law.

The more general view, however, is that this is too all-encompassing a conclusion and that under the present state of the law, the legal consequences of a breach by a state of a contractual undertaking to an alien cannot be articulated with satisfactory specificity. ${ }^{37}$ The limits of

35 Wadmond, The Sanctity of Contract Between a Sovereign and a Foreign National, in ABA, Mineral and Natural Resources Law Proceedings 177 (1957).

36 See Ray, Law Governing Contracts Between States and-Foreign Nationals, in SouthWestern Legal Foundation, 2 Proceedings of the Institute on Private Investments ABroad 36-42 (1960); Domke, Foreign Nationalizations, 55 AM. J. INT'L L. 585, 597 (1961); Schwebel, International Protection of Contractual Arrangements, 53 AM. SOc'Y INT'L LAw Proc. 266 (1959); Wehberg, Pacta Sunt Servanda, 53 AM. J. INT'L L. 775 (1959).

37 See Fatouros, op. cit. supra note 3, at 191-209, 243-301; Frueduann, The Changing Structure of International Law 170-81 (1964); Nwogugu, The Legal Problems of Foreign Investment in Developing Countries 173-97 (1965); Pugh, Legal Protection of 
state responsibility are ambiguous when the state's position is that of both sovereign and private contractor. But it may at least be expected that discriminatory exercise of governmental power in a pronounced and manifestly unfair way against the alien would appear to be a significant, if not controlling, factor in finding a violation of international law. ${ }^{38}$ There is considerable agreement that even though municipal law was made the proper law of a state contract, an "arbitrary" termination or alteration of the contract by a change made in the proper law may-in terms of the contract itself-constitute tortious conduct that possesses an internationally illegal quality. ${ }^{39}$ Moreover, there are indications that general principles of law such as unjust enrichment, estoppel, and respect for acquired rights may become increasingly applied to international law cases involving state promises to private individuals. ${ }^{40}$

Although case law does not yet provide legal rules of established validity regarding the legal responsibility of the state if it interferes with an alien's "contractual rights," the inadequacies under the local law of the foreign state and international law can be offset to some extent through protective measures adopted by the capital-exporting countries. Provisions providing some protection for foreign investment may be included in bilateral commercial treaties such as those of Friendship, Commerce and Navigation. ${ }^{41}$ Under an Investment Guaranty Program such as that administered by the Agency for International Development, the foreign investor can also be insured against loss resulting from currency inconvertibility, expropriation or confiscation, and damage to physical assets caused by war, revolution, or insurrection. ${ }^{42}$ The recently proposed international convention establishing a

International Transactions Against Non-Commercial Risks, in A LAWYER's GUIDE TO INTERnatronal Business Transactions 319-20 (Surrey \& Shaw eds. 1963); Carlston, Concession Agreements and Nationalization, 52 AM. J. INT'L L. 260-64 (1958); Jennings, State Contracts in International Law, 37 BRIT. ХB. INT'L L. 156 (1961); Mann, State Contracts and State Responsibility, 54 AM. J. INr'L L. $572-75$ (1960); Sohn \& Baxter, Responsibility of States for Injuries to the Economic Interests of Aliens, 55 AM. J. INT'L L. 545 (1961).

38 Fatouros, Legal Security for International Investment, in LEGAL ASPECTS OF FOREIGN INVESTMENT 718-19 (Friedmann \& Pugh eds. 1959); McNair, supra note 33.

39 HYde, 2 INTERnatronal LAw 991 (2d rev. ed. 1945); Jennings, supra note 37, at 163$66,181-82$.

40 Nwogugu, op. cit. supra note 37, at 62-63, 177-85; Lalive, The Doctrine of Acquired Rights, in Rights and Duties of Private Investors Abroad 183-200 (1965); Fatouros, supra note 38, at 721-24; Friedmann, Some Impacts of Social Organization on International Law, 50 AM. J. INT'L L. 475, 502-06 (1956); McNair, supra note 33, at 16-18.

41 Nwogugu, op. cit. supra note 37 , at 120-35.

4275 Stat. 429 (1961), 22 U.S.G. $\$ \S 2181-84$ (1964); Fatouros, op. cit. supra note 3, at 111-17; Nwogugu, op. cit. supra note 37, at 67-79; Whitman, The UnIted States Investment Guaranty Program and Private foreign Investment (1959); Clubb \& Vance, supra note 3, at 487-502; Snyder, supra note 2, at 1092-96. 
conciliation and arbitration service under the auspices of the World Bank (IBRD) also has potential value from the procedural standpoint in providing institutional facilities for the settlement of investment disputes. ${ }^{43}$

More significant to the private investor than the adequacy of the guarantees under international law, however, is the probability of breach of the instrument of approval by the host government. Thus, the very act of the country's screening process under an investment law may be interpreted as offering more effective protection than private foreign capital has hitherto enjoyed in developing countries. For if the foreign investment regulations now result in an exclusion of undesired investments, there is at the same time opportunity for extensive negotiation and greater security for the particular investment that is admitted with a special instrument of approval. Discrimination against certain types of foreign investment is exercised at the outset, but the discouragement is not indiscriminate. The corollary is that those investments with "approved status" may look forward to "sympathetic consideration"; the probability of breach is lessened when the host government participates in the initial investment decision.

\section{Conclusion}

The experience of the last two decades has indicated that the most decisive determinant of the flow of private capital to the underdeveloped countries is the policies of those underdeveloped countries toward private foreign investment. After a period of hostility toward private foreign investment, many underdeveloped countries are now actively promoting such investment under conditions established by foreign investment laws. This article has attempted to analyze the benefits and costs of various policies of the underdeveloped countries in light of their effects on the underdeveloped country's allocation of resources, distribution of income, and balance of payments.

If a foreign investment law has any effect, it is to relate public policy and private action to each other. As long as the host country remains serious about accelerating its development, the continued beneficial economic performance of foreign investment (in terms of our analysis, a high benefit-cost ratio) will be the decisive determinant of the investment's security. Given the uncertainties surrounding sub-

43 The convention establishing an International Center for Settlement of Investment Disputes as an autonomous international institution under the auspices of the World Bank was approved March 18, 1965, by the Executive Directors of the World Bank and submitted to the Bank's 102 member nations for their approval. The convention enters into force after it has been signed and ratified by twenty governments. 
stantive principles of law in this area, the emphasis must be on the negotiation of terms in specific ad hoc agreements, with the ultimate source of security residing in the underlying community of interest between investor and host country. In the context of national development objectives, the greatest value of a foreign investment statute may prove to be its potential for perceiving this community of interest in explicit terms-first at the initial stage of negotiating a foreign investment-development agreement, and subsequently in eliciting the continuing contribution of the foreign investment to the development goals of the host country. We may therefore conclude that a benefitcost analysis and the economic realities of the development process are now of higher importance for the protection of private foreign investment than are the legal doctrines that have hitherto dominated and artificially limited the approach to this problem. 